\section{Intersections}

Canadian Journal of Music

Revue canadienne de musique
Intersections CANADIAN JOURAL OF MUSIC
REVUE CANADIENEE DE MUSIOUH

\title{
Demographics of Tenure-Stream Music Faculty in Canadian Post-secondary Institutions
}

\section{Louis Bergonzi, Deanna Yerichuk, Kiera Galway et Elizabeth Gould}

Volume 35, numéro 1, 2015

URI : https://id.erudit.org/iderudit/1038945ar

DOI : https://doi.org/10.7202/1038945ar

Aller au sommaire du numéro

\section{Éditeur(s)}

Canadian University Music Society / Société de musique des universités canadiennes

\section{ISSN}

1911-0146 (imprimé)

1918-512X (numérique)

Découvrir la revue

Citer cet article

Bergonzi, L., Yerichuk, D., Galway, K. \& Gould, E. (2015). Demographics of Tenure-Stream Music Faculty in Canadian Post-secondary Institutions. Intersections, 35(1), 79-104. https://doi.org/10.7202/1038945ar
Résumé de l'article

Cette étude donne un aperçu de l'obtention de la permanence dans les institutions canadiennes universitaires d'enseignement de la musique, en se concentrant en particulier sur les facteurs de genre et de race/ethnicité. Les données montrent que la permanence a été octroyée à un taux élevé sur une période de cinq ans, et que les femmes n'ont pas plus ou moins de chances de l'obtenir que les hommes. Cependant, il a été observé que plus d'hommes que de femmes occupent les postes réunis avec permanence et menant à la permanence, et ce, dans une proportion de 2 à 1 . L'échantillon des professeurs non-blanc n'était pas suffisamment important pour effectuer des analyses statistiques sur les taux de permanence en rapport avec la race et l'ethnicité, bien que les taux très bas de non-blancs à des postes menant à la permanence suggèrent que la diversité demeure une préoccupation dans les programmes postsecondaires d'enseignement de la musique.
Copyright ( C Canadian University Music Society / Société de musique des universités canadiennes, 2016
Ce document est protégé par la loi sur le droit d'auteur. L'utilisation des services d’Érudit (y compris la reproduction) est assujettie à sa politique d'utilisation que vous pouvez consulter en ligne.

https://apropos.erudit.org/fr/usagers/politique-dutilisation/ 


\title{
DEMOGRAPHICS OF TENURE-STREAM MUSIC FACULTY IN CANADIAN POST-SECONDARY INSTITUTIONS
}

\author{
Louis Bergonzi, Deanna Yerichuk, Kiera Galway, and Elizabeth Gould
}

\section{INTRODUCTION}

The tenure process is a defining element of the workplace culture in Canada's post-secondary music institutions and plays a key role in the lives of most academics, functioning simultaneously as an implicit basis for hiring, a mechanism for retention and initial promotion experience. Although it is a strongly contested and fraught system, tenure is a critical measure by which academic success is assessed and career stability achieved.

Despite the importance of tenure to Canadian universities, there is a lack of comprehensive, trustworthy research on demographics of music faculty in post-secondary institutions, the tenure process itself, and its impact on the lived experience of those involved. While research on post-secondary music institutions in the United States has been ongoing since the early 1970s, studies investigating the demographics of Canadian post-secondary music institutions are noticeably absent. McLean and Jobin-Bevans's 2009 survey collected general data on Canada's various post-secondary music institutions, including information on enrolment, staffing, programs, facilities, and student-to-faculty ratios. Their survey provides a useful and necessary starting point, albeit with incomplete data sets. They suggest that further, more detailed research is needed on Canadian university music institutions and call for increased collaboration among MusCan members to create and maintain information on the country's post-secondary music institutions. This suggests a need for more current, accurate statistical data on Canadian university music education, specifically demographic data on members of the professoriate.

This article aims to address the paucity of demographic information identified by McLean and Jobin-Bevans by presenting the findings in the first phase of the larger mixed-methods study, "Living with Tenure." The study, funded by the Social Sciences and Humanities Research Council of Canada, endeavoured to investigate tenure through an equity lens, paying particular

1 The first phase of the study used a survey to gather demographic information from forty-four Canadian post-secondary music institutions. The second phase employed institutional ethnography to explore the interaction of texts and people throughout the tenure process at three specific institutions. In the third phase of the project, participants shared their experiences and stories relating to the tenure process. 
attention to gender and race/ethnicity, with the overall goal of strengthening higher education in music through insights that might contribute to making the tenure process more equitable. However, we were equally motivated by the lack of data available on Canadian post-secondary music programs, particularly on faculty members. As such, the project overall was oriented to three main objectives: first, to craft a statistical snapshot specific to the Canadian post-secondary music context; second, to gain insight on the tenure process as it is institutionally regulated; and third, to animate statistical data by bringing forward narratives of individual tenure experiences. This article speaks to the first of these objectives by presenting a statistical overview of current tenure demographics in Canadian post-secondary music institutions. While the authors provide preliminary analysis of the findings, particularly through an equity lens, our primary objective is here is to provide statistical analysis and demographic data that build on the work of McLean and Jobin-Bevans (2009) to create a baseline of data specific to the Canadian context.

\section{Context And Review of The Literature}

Research on tenuring practices focuses on social groups that have historically been underrepresented in tenured positions, including women and people of colour (Cooper and Stevens 2002; Dooris and Guidos 2006). ${ }^{2}$ The bulk of this research has been conducted in the United States, suggesting a need for similar work in Canadian contexts. Research topics include, for example, adverse effects of the "double day" for women that adds responsibilities of mothering, care-giving, and domestic responsibilities to a full academic career (Armenti 2004a, 2004b3; Colbeck and Drago 2005; Finkel and Olswang 1996; Mason and Goulden 2002, 2004; Norrell and Norrell 1996; Rosen 1999; Suitor, Mecom, and Feld 2001; Wright and Young 2001). Ornstein, Stewart, and Drakich (2007) focus on Canadian post-secondary institutions, and their analysis of promotions of full-time faculty between 1984 and 1999 found not only unequal ratios between men and women faculty members but also differences between men and women in time to promotion and tenure. 4

The majority of research on tenure processes has focused on gender disparity, with less concentration on race/ethnicity. That said, a number of studies address the effects of marginalization and racism (perhaps unintended, but nonetheless real) experienced by people of colour in post-secondary contexts (Boyd, Cintrón, and Alexander-Snow 2010; Damasco and Hodges 2012; Diggs et al. 2009; Fenelon 2003; Holmes, Land, and Hinton-Hudson 2007; Perna 2001; Thomas 2006; and Trower 20025). Statistical data from both the College Music Society (CMS) and the US National Association of Schools of Music (NASM) confirm some of the problems associated with unequal representation of minorities in post-secondary music institutions.

2 Both U.S. studies.

Canadian study.

See also Stewart, Ornstein, and Drakich (2009).

All U.S. studies. 
The findings of research conducted by CMS and NASM further suggest that women and people of colour are disproportionately underrepresented among tenured faculty members at music institutions. In 2009, women earned 47 per cent of music doctoral degrees in the United States (data not available in Canada), but constituted only 36 per cent of assistant professors and 29 per cent of associate and full professors in the United States (Higher Education Arts Data Services 2010). Considering the high degree of similarity between statistics on university music professors in the United States (ibid.) and in Canada (Gould 2011), it is possible that similar disparities exist in Canada, but research is necessary to confirm this.

Our larger research project, Living with Tenure, in part updates these previous studies by focusing specifically on the tenure distribution of women and people of colour within the university music programs in Canada, as well as exploring both institutional and individual experiences of the tenure process. A necessary first step in the larger project was to provide a snapshot of current tenure demographics in Canadian post-secondary music institutions, and this article takes that first step by presenting the findings of the first phase of the larger research project.

Given the absence of such a profile, we conducted a survey to determine the socio-demographic characteristics of tenured and tenure-track faculty, focusing on representation of women and people of colour. Although recent articles in academic journals (e.g., Acker, Webber, and Smyth 2012) and trade publications (e.g., Curtis 2014) both suggest that contract positions are on the rise while tenure-track positions are disappearing, we gathered data only on tenure-track faculty members with the rationale that, as a pilot project, this research could best begin by focusing on this more clearly defined group that sets work expectations and standards in post-secondary institutions. Further, the tenure process remains the most important element in the career of an academic, offering access to employment security as well as prestige. We focus on tenure-track faculty to build a baseline of data on tenure status and tenure rates, which have not been available in Canadian post-secondary music programs.

\section{Methodology}

The objective of this phase of the research project was to collect demographic information that would provide a snapshot of tenured and tenure-track music faculty in universities across Canada, particularly related to gender and race/ ethnicity. The institutions selected to participate in the study were chosen based on three requirements: (1) having a tenure/professorial ranking system; (2) offering a four-year degree-granting system/offering a major and/or courses in music; and (3) having an administrative system for the music department or school. A survey instrument was designed to collect demographic data related to tenure and tenure rates in Canadian post-secondary music institutions that use a tenure/professorial rank system. We identified the head of each music department or school primarily through institutional websites, 
and asked them, or a designate, to complete an online survey by providing data based on the then-current 2012/13 academic year. Note that the position titles and structures of the music programs varied widely across institutions, and therefore for consistency's sake, we refer to the heads of music programs with the term of academic music executive, following the College Music Society (Miller, Werner, and Hip 2006), as well as the National Association of Schools of Music.

The survey asked a series of questions related to tenure-track faculty and the numbers of employees overall (see appendix A for the full survey). Specifically, the survey collected data on the following areas:

- Music faculty by rank, gender, race/ethnicity, primary area of appointment (current year)

- Tenure applications by gender, race/ethnicity, primary area of appointment (current year)

- Successful tenure applications by gender, race/ethnicity, primary area of appointment (current year)

- Applications to "stop" tenure clock by rank, gender, race/ethnicity, primary area of appointment (current year)

- Existence of mentorship programs (formal or informal)

- Primary area of academic appointment per tenured/tenure-track faculty member, in the categories of composition; theory; ethnomusicology; musicology; music education; conducting; brass; percussion; strings; woodwinds; jazz; piano; organ; early music; voice; opera

- Gender, collected in the categories of male and female

- Race/ethnicity, collected using the categories of Aboriginal, Black/ African descent, Caribbean, Hispanic/Latino, white non-Hispanic, Pacific Islander, South Asian (e.g., India, Pakistan, Bangladesh, Sri Lanka), East/Southeast Asian (e.g., China/Taiwan, North/South Korea, Japan, Thailand, Vietnam)

The categories of race/ethnicity were based on the categories used by the College Music Society with the assumption that these categorizations were both broad enough to be determined by an administrator about their faculty members, yet specific enough to get a sense of the ethnic diversity within music divisions of universities. The research team made slight modifications to this list to reflect terms and categories specific to Canada, drawing from ethnoracial categories used by Statistics Canada (2011).

Our selection procedures yielded a valid population of forty-eight institutions from a list of fifty-four potential post-secondary institutions developed from the directory of the College Music Society and the directory provided by the Association of Universities and Colleges of Canada. To reflect this pilot study's focus on music faculty who are tenured or on the tenure track, the researchers set three criteria for participation in the study: that the institution have a tenure process; that the institution offer degrees in music or with music requirements; and that the institution provide instruction in music. Four 
institutions were eliminated because they did not meet these criteria. ${ }^{6}$ Finally, the responding administrators had to answer three qualification questions at the beginning of survey. The results of this process further eliminated two institutions that did not meet the criteria required for participation. ${ }^{7}$

Survey refinement, distribution, and data collection took place over approximately four weeks in the summer of 2013. First, two academic music executives piloted the study, and minor revisions were made that rendered the survey usable and valid. The online survey was then distributed to administrators of post-secondary music programs via an email message that included instructions from the principal investigator and a unique email link to the survey. Using the contact information listed on schools' websites, follow-up phone calls and emails were completed to five institutions that did not receive notice of the survey, either because their administrators had pre-opted out of all invitations from the survey company; opted out of the online survey application for this study; or for which contact information was inaccurate.

Academic music executives were given fourteen days to respond before being sent a reminder email. After this, phone calls were made to confirm the updated contact information and to encourage their participation by offering them the option of completing the survey over the phone or receiving and submitting the survey as a fillable text document. Five academic music executives completed the survey via hard copy or telephone. Post hoc analysis showed that the average time to complete the survey online was twenty-one minutes, regardless of the size of the faculty, and that academic music executives spent less than a minute per faculty member completing the survey for their unit.

During this period, informal feedback from some administrators indicated that estimates of full-time equivalents (Question \#14) were difficult for some to calculate. In light of this information, a revised version of the survey was created with this survey item as optional. This modification resulted in four additional responses. At the end of the response period, twenty-eight responses (58.3 per cent) had been received.

Data were analyzed using SPSS software (v. 22; IBM 2013). Pairwise deletion was used in our analyses, so that for each analysis cases with missing data were not used. Pairwise deletion attempts to minimize loss that occurs by deleting all cases with data missing for any single variable in the data set. For this reason, we calculated and reported a separate valid $n$ for each analysis.

6 Their ineligibility was determined through the research team's first-hand knowledge of these institutions. The accuracy of our conclusions was subsequently confirmed by examining each institution's online materials.

7 The three qualification survey questions were: (1) Does the administrative unit for which you are responsible have a process for professorial rank faculty tenure? (2) Does the administrative unit for which you are responsible offer a four-year or four-plus-year degree or major in music, or include music-related instruction as a part of your four-plus-year degree or after-degree programs?, and (3) Does the administrative unit for which you are responsible have one of the following: (a) a faculty dedicated to music instruction; (b) a university school of music or conservatory; or (b) music instruction that exists as part of a larger faculty, department, or administrative unit? 


\section{Representativeness of Responses}

To assess the representativeness of the data obtained, the randomness of nonrespondents was examined relative to the type of institution as determined by the 2013 Maclean's university annual rankings of universities (Dehaas 2012). As part of its excellence ranking procedures, Maclean's categorizes all Canadian colleges and universities into three groups according to "differences in levels of research funding, diversity of offerings and breadth and depth of graduate and professional programs" (Dwyer 2013). The response rates for comprehensive, medical/doctoral, and primarily undergraduate categories, were $62.5,76.5$, and 33.3, respectively (table 1 ).

Table 1. Response rates and status by institution type

\begin{tabular}{|c|c|c|c|c|c|c|}
\hline & & & \multicolumn{3}{|c|}{ Institution type } & \multirow[b]{2}{*}{ Total $(\%)$} \\
\hline & & & Comprehensive & $\begin{array}{l}\text { Medical } \\
\text { doctoral }\end{array}$ & Undergrad & \\
\hline \multirow[t]{10}{*}{ Responded } & No & Count & 6 & 4 & 10 & 20 \\
\hline & & Expected count & 6.7 & 7.1 & 6.3 & \\
\hline & & $\%$ within respondent & $30.0 \%$ & $20.0 \%$ & $50.0 \%$ & $100 \%$ \\
\hline & & $\begin{array}{l}\% \text { within institution } \\
\text { type }\end{array}$ & $37.5 \%$ & $23.5 \%$ & $66.7 \%$ & $41.7 \%$ \\
\hline & & $\%$ of total & $12.5 \%$ & $8.3 \%$ & $20.8 \%$ & \\
\hline & Yes & Count & 10 & 13 & 5 & 28 \\
\hline & & Expected count & 9.3 & 9.9 & 8.8 & \\
\hline & & $\%$ within respondent & $35.7 \%$ & $46.4 \%$ & $17.9 \%$ & $100 \%$ \\
\hline & & $\begin{array}{l}\% \text { within institution } \\
\text { type }\end{array}$ & $62.5 \%$ & $76.5 \%$ & $33.3 \%$ & $58.3 \%$ \\
\hline & & $\%$ of total & $20.8 \%$ & $27.1 \%$ & $10.4 \%$ & \\
\hline \multirow{2}{*}{\multicolumn{2}{|c|}{ Total }} & Count & 16 & 17 & 15 & 48 \\
\hline & & $\%$ of total & $33.3 \%$ & $35.4 \%$ & $31.3 \%$ & $100 \%$ \\
\hline
\end{tabular}

Note: Expected counts are the counts one would expect if there were no relationship between the institution type and whether an institution responded or not.

A chi-square test of independence to determine the randomness of the nonrespondents relative to distribution of schools by Maclean's categories was significant, $\chi^{2}(2, N=48)=6.27, p=.043$. In other words, whether or not a school responded depended on what type of institution it was, and institutions that were primarily undergraduate were less likely to have completed the survey than comprehensive or medical/doctoral institutions. Therefore, any conclusions about schools of music in Canada as a whole are biased by the non-random pattern of responders and non-responders related to institution type.

However, the interpretive importance of this statistical relationship is meaningful relative only to any extent that institution type corresponds: (1) to the gender distribution of faculty, and (2) to expectations and procedures related to tenure. Our own supplemental analysis and the work of Ornstein, Stewart, and Drakich (2007) indicate that expectations related to tenure and 
promotion of music faculty do not vary by institution type. ${ }^{8}$ Therefore, and with a response rate of 58 per cent, we consider the data from our survey as functionally representative of all Canadian music programs.

\section{RESULTS}

\section{Description of Music Faculty}

According to the survey responses, 84 per cent of tenure-stream faculty members in Canadian post-secondary music institutions are tenured (table 2). Tenure-stream faculty represent only 34 per cent of all faculty appointments in music.

The size of faculty was also determined by summing the number of individual faculty profiles recorded in the final question of the survey (Q12) for which respondents recorded the gender, race/ethnicity, rank, primary appointment area, and tenure status during 2012-13 of each full-time tenure-stream faculty member. Respondents also answered questions about tenure action over the previous five years (2008-9) up to and including the most recent 2012-13 academic year.

Since the 2008-9 academic year, sixty faculty members were awarded tenure, three were denied, and one was eligible but deferred (table 4). This rate of acting on tenure-eligible faculty, about ten per year, occurred also for the year 2012-13, during which eleven tenure applications were submitted that resulted in six approvals, four delayed decisions, and one deferred application.

8 The first consideration was investigated by supplemental analysis, the results of which showed that gender and institution type were not related, $\chi^{2}(2, N=286)=0.061, p=.97$ for the music faculty across ranks, or among a subgroup of non-tenured assistant professors, $\chi^{2}(2, N=45)=0.1 .33$, $p<.05$. We also note that the randomness of these relationships was stable, whether or not the five tenured assistant professors (see table 3 for details) were included among the rank of tenured faculty.

For the second consideration regarding expectations and procedures related to tenure, Ornstein, Stewart, and Drakich (2007), using data about all Canadian tertiary faculties, investigated promotion, gender, discipline, and institution type (using the Maclean's categories used in the current study). Their results indicated that variation in the time to promotion by institution type was greater than variation by gender and among disciplines. Time to tenure, however, is not analogous to difference in tenure expectations. Indeed, in describing the context their study, Ornstein, Stewart, and Drakich note how a general escalation of the importance of research for promotion and tenure has homogenized "formal expectations of research, teaching, and service" across undergraduate, graduate, and professional faculties (3). Members of the current study's research team from Canada believed that this was also the case for music faculties. 
Table 2. Description of music faculties by tenure status ${ }^{\text {a }}$ (responders $N=28$ )

\begin{tabular}{|c|c|c|c|c|c|}
\hline & $\begin{array}{r}\text { Missing } \\
\text { data }\end{array}$ & $n$ & Mean & Max & Source question \\
\hline Total faculty size & & & & & \multirow{3}{*}{$\begin{array}{l}\text { Q4: How many music-specific } \\
\text { faculty members are there in your } \\
\text { administrative unit? Consider all } \\
\text { types of appointment: clinical or } \\
\text { other non-tenure track, tenured, and } \\
\text { in tenure track. }\end{array}$} \\
\hline Full-time equivalent & 1 & 496.01 & 18.37 & 56.74 & \\
\hline Head count & 3 & 850 & 33 & 122 & \\
\hline Tenure stream faculty & & 286 & & & \multirow{3}{*}{$\begin{array}{l}\text { Q12: Final section of the survey } \\
\text { focuses on ... currently tenured or } \\
\text { tenure-stream professorial rank } \\
\text { music faculty, including those about } \\
\text { whom a tenure action or decision } \\
\text { was made during } 2012-13 . . . \text { and } \\
\text { their tenure status during the } \\
\text { just-completed academic year, the } \\
2012-13 \text { academic year. }\end{array}$} \\
\hline Tenured & & 229 & & & \\
\hline Not yet tenured & & $57^{c}$ & & & \\
\hline Tenure action last 5 years & 1 & 64 & & & \multirow{4}{*}{$\begin{array}{l}\text { Q6: Over the last } 5 \text { academic years } \\
\text { (in other words, beginning with } \\
2008-9 \text { ), how many of these profes- } \\
\text { sorial-rank faculty members (head } \\
\text { count) applied for and received } \\
\text { tenure? }\end{array}$} \\
\hline Applied-awarded & 1 & 60 & & & \\
\hline Applied_denied & 1 & 1 & & & \\
\hline Deferred application & 2 & 3 & & & \\
\hline
\end{tabular}

a Survey questions do not necessarily capture faculty from Institution A who were hired at Institution B with tenure. b This includes all types of appointments, clinical, other non-tenure, and tenure track.

c In addition to head counts reported here, we asked academic music executives to quantify faculty size as full-time equivalencies (FTE). A separate question (Q5) was asked about full-time equivalents and head counts for tenurestream faculty members who were not yet tenured (head count $=42$ ). Results indicate that most of the difference is attributable to the number of faculty about whom tenure action was taken during 2012-13 (table 4).

Table 3. Tenure-stream faculty by rank, gender, race/ethnicity, primary appointment, and tenure status (Fall 2012)

\begin{tabular}{llrr}
\hline Characteristic & & Count & Valid \% \\
\hline Rank $^{\mathrm{a}}$ & Assistant professor, without tenure & 45 & 15.7 \\
& Assistant professor, with tenure & 5 & 1.7 \\
& Associate professor, without tenure & 7 & 2.4 \\
& Associate professor, with tenure & 130 & 45.5 \\
& Full professor & 99 & 34.6 \\
& Valid $n$ & 286 & 33.3 \\
Gender & Female & 95 & 66.7
\end{tabular}




\begin{tabular}{|c|c|c|c|}
\hline \multicolumn{2}{|l|}{ Characteristic (cont'd) } & \multirow{2}{*}{$\begin{array}{r}\text { Count } \\
1\end{array}$} & \multirow{2}{*}{$\begin{array}{r}\text { Valid } \% \\
0.4\end{array}$} \\
\hline Race/ethnicity ${ }^{b}$ & Bi-racial or mixed race & & \\
\hline & Black/African descent & 4 & 1.4 \\
\hline & Caribbean & 1 & 0.4 \\
\hline & $\begin{array}{l}\text { East/Southeast Asian (e.g., China/Taiwan, North and } \\
\text { South Korea, Japan, Thailand }\end{array}$ & 7 & 2.5 \\
\hline & First Nations, Inuit, Metis & 0 & 0 \\
\hline & Hispanic/Latino & 3 & 1.1 \\
\hline & Pacific islander & 0 & 0 \\
\hline & $\begin{array}{l}\text { South Asian (e.g,. India, Pakistan, Bangladesh, Sri } \\
\text { Lanka) }\end{array}$ & 5 & 1.8 \\
\hline & White non-Hispanic & 255 & 91.4 \\
\hline & Uncertain & 3 & 1.1 \\
\hline & Valid $n$ & 279 & \\
\hline \multirow[t]{23}{*}{ Primary appointment } & Brass & 3 & 1.1 \\
\hline & Composition & 32 & 11.3 \\
\hline & Conducting: choral & 16 & 5.7 \\
\hline & Conducting: orchestra & 6 & 2.1 \\
\hline & Conducting: winds/percussion/bands & 5 & 1.8 \\
\hline & Early music & 3 & 1.1 \\
\hline & Ethnomusicology & 13 & 4.6 \\
\hline & Jazz & 13 & 4.6 \\
\hline & Music business/administration & 0 & 0 \\
\hline & Music technology & 10 & 3.5 \\
\hline & Music theory & 28 & 9.9 \\
\hline & Music therapy & 4 & 1.4 \\
\hline & Music education & 22 & 7.8 \\
\hline & Musicology/historical musicology & 48 & 16.6 \\
\hline & Opera/musical theatre & 1 & 0.4 \\
\hline & Percussion & 4 & 1.4 \\
\hline & Piano/organ/keyboard & 35 & 12.4 \\
\hline & Popular music & 2 & 0.7 \\
\hline & Strings & 15 & 5.3 \\
\hline & Voice & 15 & 5.3 \\
\hline & Woodwinds & 9 & 3.2 \\
\hline & World music & 0 & 0 \\
\hline & Valid $n$ & 284 & \\
\hline
\end{tabular}

a Ten responses to Q12.5 about tenure status were left blank. Assuming this was unintentional, and because the rank of these faculty members was indicated to be "Full Professor" or Associate Professor with Tenure," we assumed the correct response to Q12.5 about tenure status for these faculty members to be "Already tenured: no tenure action needed or taken during 2012-13."

b The "uncertain" option was selected only 3 times; the race/ethnicity question was left blank by only a single institution. This suggests that data on faculty race/ethnicity are available to academic music executives. 
Table 4. Tenure status and actions taken, 2012-13 academic year (Q12)

\begin{tabular}{lrr}
\hline Status & $n$ & Valid \% \\
\hline Already tenured: No tenure action needed or taken during 2012-13 & 233 & 81.5 \\
Non-tenured: No tenure action needed or taken during 2012-13 & 41 & 14.3 \\
Tenure was approved during 2012-13 & 7 & 2.4 \\
Tenure was denied 2012-13 & 0 & 0 \\
Tenure was applied for during 2012-13, but a decision was deferred & 4 \\
Was eligible to apply for tenure 2012-13; did not apply & 1 & 0.3 \\
Total & 286 & \\
\hline
\end{tabular}

Tenure actions according to gender can be described, but differences in tenure actions by gender cannot be determined because cell sizes were small (table 5).

Table 5. Tenure action taken by gender (2012-13)

\begin{tabular}{llrrr}
\hline & & \multicolumn{2}{c}{ Gender } & \\
Tenure action during $2012-13$ & Female & Male & Total \\
\cline { 3 - 4 } Applied, approved & Count & 3 & 7 \\
& \% within tenure status & 42.9 & 57.1 & 100.0 \\
& \% within gender & 60.0 & 57.1 & 58.3 \\
Applied, deferred & Count & 1 & 3 & 4 \\
& \% within tenure status & 25.0 & 75.0 & 100.0 \\
& \% within gender & 20.0 & 42.9 & 33.3 \\
Eligible, did not apply & Count & 1 & 0 & 1 \\
& \% within tenure status & 100.0 & 0.0 & 100.0 \\
& \% within gender & 20.0 & 0.0 & 8.3 \\
Total & Count & 5 & 7 & 12 \\
& \% within tenure status & 41.7 & 100.0 \\
& \% within gender & 100.0 & 100.0 & 100.0 \\
\hline
\end{tabular}

Note: Cell sizes too small to determine statistical significance.

\section{FACULTY SOCIODEMOGRAPHICS}

In this sociodemographic profile of Canadian music faculties, analyses focus on whether the nature of the relationship between tenure and gender is one that is random, i.e., without bias or predictability.

Music faculties are overwhelmingly male, at a rate of about 2:1 (66.7 male, and 33.3 female; table 6), a rate that has remained stubbornly consistent for the past forty years. ${ }^{9}$ Further, this ratio is likely to remain consistent in the

9 The proportion of women music faculty members in the United States in 1976 was 24.2 per cent (Neuls-Bates 1976), growing to 31 per cent by 1986 (Block 1988). However, by 1993, an American study using statistics derived from the CMS directory found that women still comprised only 33.6 per cent of all US music faculty members-of that number, 75 per cent were employed in "two-year institutions, community colleges, or in part-time, unranked positions" (Payne 1996, 98). In a 2008-9 survey completed by institutional members of the US-based National Association of Schools of Music (NASM) and volunteer non-member institutions (621 total, approximately one-third of the CMS dir- 
foreseeable future, given that males make up 71.1 per cent of pre-tenure faculty members. There is no compensatory cadre of female faculty members in line for eventual tenure consideration, suggesting that males continue to be hired into tenure-track positions twice as frequently as females. While men are more likely to be in the tenure stream, the rate of achieving tenure in music faculties in Canada is statistically independent of gender $\chi^{2}(N=285)=0.475(p=$ .49)..$^{10}$ In short, knowing something about a person's gender does not indicate anything about her or his tenure status.

Table 6: Tenure status Fall 2012 by gender

\begin{tabular}{llrrr}
\hline \multirow{2}{*}{ Gender } & & \multicolumn{2}{c}{ Tenure status } & \\
\cline { 3 - 4 } & & Not tenured & Tenured & Total \\
\hline Female & Count & 13 & 82 \\
& Expected count & 15 & 80 & \\
& \% within gender & $13.7 \%$ & $86.3 \%$ & $100.0 \%$ \\
Male & \% within tenure status & $28.9 \%$ & $34.2 \%$ & $33.3 \%$ \\
& Count & 32 & 158 & $100.0 \%$ \\
Total & Expected count & 30 & 160 & $66.7 \%$ \\
& \% within gender & $16.8 \%$ & $83.2 \%$ & 285 \\
\hline & Count & $71.1 \%$ & $65.8 \%$ & $100.0 \%$ \\
\hline
\end{tabular}

Note: Tenure status was recoded from responses to Rank (Q12.01) as the more reliable option over Q12.5, tenure status during 2012-13.

One respondent from a comprehensive school did not complete the section on faculty demographics in the survey. Thus, the valid number of institutions reporting the data used here is reduced to 27 .

In contrast, gender was significantly related to specialization area (table 7). Looking at specializations with ten or more members and for differences of more than one person than expected, given overall proportions, there is a significantly disproportionate number of women not specializing in composition, technology, and strings. Males are underrepresented in music education, musicology/historical musicology, and voice $(p \leq .01)$. Men and women serve in expected proportions as teachers of choral conducting, ethnomusicology, jazz, music theory, and piano/organ/keyboard. In consideration of these results, one must keep in mind that there are full-time appointments that are categorized solely by the faculty members' primary specialization. It does not capture faculty who are part-time and/or specialize in more than one area. Even a cursory view of MusCan data suggests that that further research is needed to inventory and analyze membership of these faculty subgroups.

ectory), women comprised 30.4 per cent of music faculty members (Higher Education Arts Data Services 2010). In the Canadian context, near identical percentages were presented by Ornstein, Stewart, and Drakich in 2007 for Canadian post-secondary institutions overall, and for music faculty first by Gould's 2011 preliminary study now confirmed through this survey.

10 The randomness of these relationships was evidenced whether or not the five tenured assistant professors were included among the ranks of tenured or non-tenured faculty. 
The related distributions between specialization and gender might be a latent influence on any relationship between gender and tenure. However, no relationship was found between tenure status and specialization $(p>.05)$.

Table 7 . Gender by specialization

\begin{tabular}{|c|c|c|c|c|}
\hline \multirow[b]{2}{*}{ Specialization } & & \multicolumn{2}{|c|}{ Gender } & \multirow[b]{2}{*}{ Total } \\
\hline & & Female & Male & \\
\hline \multirow[t]{4}{*}{ Brass } & Count & 1 & 2 & 3 \\
\hline & Expected count & 1.0 & 2.0 & 3.0 \\
\hline & $\%$ within primary appointment & 33.3 & 66.7 & 100.0 \\
\hline & within gender & 1.1 & 1.0 & 1.1 \\
\hline \multirow[t]{4}{*}{ Composition } & Count & 3 & 28 & 31 \\
\hline & Expected count & 10.2 & 20.8 & 31.0 \\
\hline & $\%$ within primary appointment & 9.7 & 90.3 & 100.0 \\
\hline & within gender & 3.2 & 14.7 & 10.9 \\
\hline \multirow{4}{*}{$\begin{array}{l}\text { Conducting: } \\
\text { choral }\end{array}$} & Count & 6 & 10 & 16 \\
\hline & Expected count & 5.2 & 10.8 & 16.0 \\
\hline & $\%$ within primary appointment & 37.5 & 62.5 & 100.0 \\
\hline & within gender & 6.5 & 5.2 & 5.6 \\
\hline \multirow{4}{*}{$\begin{array}{l}\text { Conducting: } \\
\text { orchestra }\end{array}$} & Count & 0 & 6 & 6 \\
\hline & Expected count & 2.0 & 4.0 & 6.0 \\
\hline & $\%$ within primary appointment & 0.0 & 100.0 & 100.0 \\
\hline & within gender & 0.0 & 3.1 & 2.1 \\
\hline \multirow{4}{*}{$\begin{array}{l}\text { Conducting: } \\
\text { winds/ } \\
\text { percussion/ } \\
\text { bands }\end{array}$} & Count & 3 & 2 & 5 \\
\hline & Expected count & 1.6 & 3.4 & 5.0 \\
\hline & $\%$ within primary appointment & 60.0 & 40.0 & 100.0 \\
\hline & within gender & 3.2 & 1.0 & 1.8 \\
\hline \multirow[t]{4}{*}{ Early music } & Count & 1 & 2 & 3 \\
\hline & Expected count & 1.0 & 2.0 & 3.0 \\
\hline & $\%$ within primary appointment & 33.3 & 66.7 & 100.0 \\
\hline & within gender & 1.1 & 1.0 & 1.1 \\
\hline \multirow[t]{4}{*}{ Ethnomusicology } & Count & 4 & 9 & 13 \\
\hline & Expected count & 4.3 & 8.7 & 13.0 \\
\hline & $\%$ within primary appointment & 30.8 & 69.2 & 100.0 \\
\hline & within gender & 4.3 & 4.7 & 4.6 \\
\hline \multirow[t]{4}{*}{ Jazz } & Count & 3 & 10 & 13 \\
\hline & Expected count & 4.3 & 8.7 & 13.0 \\
\hline & $\%$ within primary appointment & 23.1 & 76.9 & 100.0 \\
\hline & within gender & 3.2 & 5.2 & 4.6 \\
\hline
\end{tabular}




\begin{tabular}{|c|c|c|c|c|}
\hline \multirow{2}{*}{\multicolumn{2}{|c|}{ Specialization (cont'd) }} & \multicolumn{2}{|c|}{ Gender } & \multirow{3}{*}{$\begin{array}{r}\text { Total } \\
10\end{array}$} \\
\hline & & \multirow{2}{*}{$\begin{array}{r}\text { Female } \\
0\end{array}$} & \multirow{2}{*}{$\begin{array}{r}\text { Male } \\
10\end{array}$} & \\
\hline Music & Count & & & \\
\hline & Expected count & 3.3 & 6.7 & 10.0 \\
\hline & $\%$ within primary appointment & 0.0 & 100.0 & 100.0 \\
\hline & within gender & 0.0 & 5.2 & 3.5 \\
\hline \multirow[t]{4}{*}{ Music theory } & Count & 10 & 18 & 28 \\
\hline & Expected count & 9.2 & 18.8 & 28.0 \\
\hline & $\%$ within primary appointment & 35.7 & 64.3 & 100.0 \\
\hline & within gender & 10.8 & 9.4 & 9.9 \\
\hline \multirow[t]{4}{*}{ Music therapy } & Count & 2 & 2 & 4 \\
\hline & Expected count & 1.3 & 2.7 & 4.0 \\
\hline & $\%$ within primary appointment & 50.0 & 50.0 & 100.0 \\
\hline & within gender & 2.2 & 1.0 & 1.4 \\
\hline \multirow[t]{4}{*}{ Music education } & Count & 10 & 12 & 22 \\
\hline & Expected count & 7.2 & 14.8 & 22.0 \\
\hline & $\%$ within primary appointment & 45.5 & 54.5 & 100.0 \\
\hline & within gender & 10.8 & 6.3 & 7.7 \\
\hline \multirow{4}{*}{$\begin{array}{l}\text { Musicology/ } \\
\text { historical } \\
\text { musicology }\end{array}$} & Count & 22 & 26 & 48 \\
\hline & Expected count & 15.7 & 32.3 & 48.0 \\
\hline & $\%$ within primary appointment & 45.8 & 54.2 & 100.0 \\
\hline & within gender & 23.7 & 13.6 & 16.9 \\
\hline \multirow{4}{*}{$\begin{array}{l}\text { Opera/musical } \\
\text { theatre }\end{array}$} & Count & 1 & 0 & 1 \\
\hline & Expected count & .3 & .7 & 1.0 \\
\hline & $\%$ within primary appointment & 100.0 & 0.0 & 100.0 \\
\hline & within gender & 1.1 & 0.0 & 0.4 \\
\hline \multirow[t]{4}{*}{ Percussion } & Count & 0 & 4 & 4 \\
\hline & Expected count & 1.3 & 2.7 & 4.0 \\
\hline & $\%$ within primary appointment & 0.0 & 100.0 & 100.0 \\
\hline & within gender & 0.0 & 2.1 & 1.4 \\
\hline \multirow{4}{*}{$\begin{array}{l}\text { Piano/organ/ } \\
\text { keyboard }\end{array}$} & Count & 14 & 21 & 35 \\
\hline & Expected count & 11.5 & 23.5 & 35.0 \\
\hline & $\%$ within primary appointment & 40.0 & 60.0 & 100.0 \\
\hline & within gender & 15.1 & 11.0 & 12.3 \\
\hline \multirow[t]{4}{*}{ Popular Music } & Count & 0 & 3 & 3 \\
\hline & Expected count & 1.0 & 2.0 & 3.0 \\
\hline & $\%$ within primary appointment & 0.0 & 100.0 & 100.0 \\
\hline & within gender & 0.0 & 1.6 & 1.1 \\
\hline
\end{tabular}




\begin{tabular}{llrrr}
\hline & & \multicolumn{2}{c}{ Gender } & \\
\cline { 3 - 4 } Specialization (cont'd) & Female & Male & Total \\
\hline \multirow{2}{*}{ Strings } & Count & 2 & 13 & 15 \\
& Expected count & 4.9 & 10.1 & 15.0 \\
& \% within primary appointment & 13.3 & 86.7 & 100.0 \\
& within gender & 2.2 & 6.8 & 5.3 \\
\multirow{2}{*}{ Voice } & Count & 8 & 7 & 15 \\
& Expected count & 4.9 & 10.1 & 15.0 \\
& \% within primary appointment & 53.3 & 46.7 & 100.0 \\
\multirow{4}{*}{ Woodwinds } & 8.6 & 3.7 & 5.3 \\
& within gender & 3 & 6 & 9 \\
& Count & 2.9 & 6.1 & 9.0 \\
& Expected count & 33.3 & 66.7 & 100.0 \\
& \% within primary appointment & 3.2 & 3.1 & 3.2 \\
\hline
\end{tabular}

Note: Contingency coefficient $=.333 . p \approx .012$. Valid $N=284$

\section{Supportive Structure for Non-Tenured Faculty: Pausing Clock And Mentoring}

Formal mentoring programs are rare, whereas allowing faculty to suspend the tenure clock is common. Allowing pre-tenure faculty to request a pause in the tenure clock is possible at twenty-one of twenty-eight institutions. Mentoring programs are almost inversely rare to the ability to pause the clock, with only 32 per cent of valid respondents answering in the affirmative to the question about whether their institution has "a formal mentoring program for tenure track faculty that occurs on a regular, systematic basis." The four respondents who chose the "Other" option to this question offered statements, which are included in Appendix B. One comment about the nature of alternatives to mentoring is offered here as summary of the collection of four: "No mentoring per $s e$, but clear information and feedback that is fundamentally important for a candidate's success."

\section{TENURE AND RACE/EThNiCITY}

The survey also asked respondents to provide demographic data on the ethnicity/ race of their tenure-track faculty. Of the 280 tenure-stream faculty reported in the survey, fully 256 tenure-track faculty were reported as white, non-Hispanic. The next highest category was Eastern/Southeast Asian, with 7 tenure-track faculty (refer to table 3). Because of such low sample sizes in any category besides the "white, non-Hispanic" category, inferences could not be drawn about the relationships between race and tenure, or race and specialization. 


\section{Discussion}

In Canadian university music divisions, professors are tenured at an extremely high rate: of the tenure decisions made in the 2012-13 academic year, not one institution reported denying tenure to any faculty member who applied, echoing the findings of Stewart, Ornstein, and Drakich (2009) on Canadian postsecondary faculty overall. However, several respondents reported that four applicants (three male, one female) deferred the tenure decision, and there was one reported case of a female professor being eligible, but choosing not to apply for tenure (see appendix D for a full list of respondent comments related to tenure decisions). ${ }^{11}$

What analysis of the current study did find was that the distribution of tenure is statistically independent of gender, meaning that females are no more or less likely than males to be tenured, again confirming the findings of Stewart, Ornstein, and Drakich (2009). However, Canadian post-secondary music institutions have a much higher proportion of male tenure-track faculty overall, at a rate of about 2:1, a rate that has remained obstinately constant since Adrienne Block $(1974,1988)$ first started studying tenure and gender in postsecondary music programs. Perhaps more importantly, our analyses indicate that this distribution is not going to be changing anytime soon: while males represented approximately two of three of faculty who already had tenure in the 2012-13 academic year, males comprised an even larger proportion of faculty who had not yet achieved tenure ( 71 per cent). This suggests that, despite affirmative action policies ostensibly adopted by Canadian universities in previous decades, men continue to be hired at twice the rate of women into tenure-track positions. What affirmative action policies have been adopted and implemented by institutions warrants further investigation, as do processes for recruiting and hiring tenure-stream faculty. While gender appears to be a factor in these processes, it is unclear how. Perhaps, as Acker, Webber, and Smyth (2012) argue, the experiences and processes of tenure may be highly gendered even while tenure rates between men and women are commensurate. We anticipate gaining some insight into these questions through the second phase of research underway, which is studying the tenure processes of three Canadian post-secondary music programs.

Results of data analyses suggest that women's and men's primary appointment to a specialization occurs disproportionately to their representation across the entire music faculty in Canada. For example, women are underrepresented as specialists in composition, technology, and strings, while they dominate in music education, musicology-historical musicology, and voice. Further research is needed to investigate the relationship between gender and specialization to understand the factors at play that shift the gender ratios among subdisciplines.

11 Future phases of the larger research project, Living with Tenure, of which the current study is the initial part, will focus on the tenure process itself, both from the perspective of the institutions overseeing the tenure process, and from the perspective of those in the tenure stream. We anticipate that these upcoming phases of research will offer insight into whose applications are being deferred or not, and the reasons behind this. 
In examining race/ethnicity among tenure-track music professors, results point to a stunning imbalance in Canadian post-secondary music programs. Consider the simple tally of the responding institutions to the survey: if all categories besides "white, non-Hispanic" were combined, including the "uncertain" category, then by that tally, the "white non-Hispanic" category accounts for 91 per cent of all reported tenure-track faculty in the survey. Consequently, it was not possible to draw any comparative conclusions about tenure in relation to race/ethnicity based on statistical analyses. Given such high rates of tenure approvals reported overall, it may be possible that race/ethnicity has as little to do with the tenure decision as gender, but the very fact of such small numbers of non-white tenure-stream faculty members should give pause for anyone concerned with the racial and ethnic representativeness of music faculty.

Findings indicate that most post-secondary institutions have formal mechanisms in place for pre-tenure faculty to take a leave of absence without detrimentally affecting their tenure process, and several comments from the survey indicate there are policies that allow for extending the tenure timeline. While neither the effectiveness of these mechanisms nor the experiences of requesting for leaves can be determined through the survey, the simple existence of such mechanisms suggests that many universities have addressed some equity concerns related to parental leave by having these policies in place. Finally, the issue of mentoring warrants closer investigation, given how few institutions report having a formal mentoring process in place for their pre-tenure faculty. At the same time, comments from the survey suggest that many institutions support their candidates using informal and ad hoc mechanisms. Further research may discover whether formal mentoring programs improve the tenure experience for tenure-track faculty, or perhaps identify promising practices in mentoring that may improve or streamline the tenure process for tenure candidates.

\section{IMPLICATIONS}

This study addresses the gap in Canadian-specific data on post-secondary music faculty, which may prove useful to academics and administrators looking for statistical data on music faculty in Canada. By producing accurate, comprehensive statistical data of post-secondary music faculties in Canada related to tenure, gender, race/ethnicity, and primary teaching area, this article provides a socio-demographic snapshot-a first step toward considering prospects for change.

What is clear from our findings is that post-secondary music faculty are the norm rather than the exception to tenure-track faculty in North American post-secondary institutions overall. Men outnumber women in tenure-track positions at a rate of 2:1, and visible minority faculty are significantly underrepresented. For post-secondary institutions that have adopted affirmative action policies over the past two decades, these stubborn results should raise questions about the effectiveness of these measures, or perhaps the effectiveness 
of their implementation. Given a recent report from NASM (Higher Education Data Services 2010) that found almost four in ten holders of doctoral degrees in music are female, it would seem that the issue is not about having a big enough pool of candidates from which to choose.

Further, the simple and somewhat shocking fact that the numbers of nonwhite tenure-track faculty are so low suggests that racial/ethnic diversity in tenure-track faculty remains an urgent equity issue facing administrators. Very little research has focused on the relationship between race and tenure, and what exists focuses mostly on American contexts. The College Music Society published a report in 1982 commissioned by the Committee on the Status of Minorities in the Profession providing summary statistical data and a call for more research, which appears to have gone unheeded. A brief report published in the Journal of Blacks in Higher Education in 2003 notes that African Americans comprise only 4.7 per cent of US music department faculties at twenty-four of what it describes as "the nation's 27 highest-ranked universities" (Anonymous 2003, 54). Factors cited as contributing to these low numbers include the less than 1 per cent of music doctorates awarded to African Americans in 2003, and institutional curricula that are heavily weighted toward the Western European canon. Further research is clearly warranted, particularly research that connects race and tenure in music faculty to questions of curricular and programmatic focus in post-secondary music programs currently dogging many administrators.

Exacerbating questions of equity within tenure-stream faculty is the overwhelming and ever-increasing body of research that shows tenure-stream faculty positions have on the whole been on a steady decline. During the past thirty-five years, data analysis in the United States has found that the number of full-time tenure-stream faculty has increased by only 23 per cent, while the number of full-time non-tenure-stream faculty has risen by 259 per cent, and part-time faculty by 289 per cent (Curtis 2014; Dobbie and Robinson 2008). Results from this study indicate that two of three music faculty appointments were not full-time tenure stream appointments in 2012-13. Disappearing fulltime tenure-stream positions are a significant concern that matters not only to faculty who must submit themselves to tenuring or face increasingly precarious work conditions, but also to academic music executives who guide tenuring processes while facing ever-increasing financial pressures in a neoliberal environment that devalues humanities in higher education. As McLean and Jobin-Bevins note, administrators must negotiate keeping enough full-time tenure-stream faculty to provide long-term stability while also keeping parttime staff who can draw from their professional experience in the music business effectively in their teaching. Yet administrators make decisions "all too often by economic constraints" rather than on the basis of "an ongoing part of a school's strategic direction" (2009, 89). Like McLean and Jobin-Bevans, we recognize the multiple pressures facing music executives, yet we assert that concerns of equity are central to operational concerns and questions of viability in an increasingly precarious post-secondary environment. 
In conclusion, this study is the first part of the larger research project Living with Tenure that will investigate processes of tenure at institutions as well as experiences of tenure from individual faculty members across Canada. It will also offer insights into the tenure process in Canadian university music programs that might improve the tenure experience for all involved in the tenure process, and perhaps offer courses of action to make the process of tenure more equitable. At the same time, these questions about tenure will also require larger conversations about the state of professorial work in Canada's post-secondary music institutions, and about programmatic focus of post-secondary music training. Living with Tenure was motivated in equal measure by a lack of data and the potential inequity represented by that data. While several important issues related to gender and race have been raised in the survey results, it is important to conclude by underscoring what McLean and Jobin-Bevans have called for: sustained efforts across Canada's post-secondary music programs are needed to collect, share, and analyze data about music programs and the people who teach them. In-depth analysis and possibilities for change are possible only when reliable and transparent data are available. Several organizations in the United States collect detailed demographic data on music faculty, but the paucity of similar data in Canada means that there simply isn't a baseline of knowledge from which to make informed policy decisions or recommendations.

\section{REFERENCES}

Acker, Sandra, Michelle Webber, and Elizabeth Smyth. 2012. "Tenure Troubles and Equity Matter in Canadian Academe." British Journal of Sociology in Education 33 (5): 743-61, DOI: 10.10801/01425692.2012.674789.

Anonymous. 2003. "The Status of Black Faculty in the Music Departments of the Nation's Highest-Ranked Universities." Journal of Blacks in Higher Education 39:54-55.

Armenti, Carmen. 2004a. "Gender as a Barrier for Women with Children in Academe." Canadian Journal of Higher Education 34 (1): 1-26.

- 2004b. "May Babies and Posttenure Babies: Maternal Decisions of Women Professors." Review of Higher Education 27 (2): 211-31.

Block, Adrienne. 1988. "The Status of Women in College Music, 1986-87." In Women's Studies/Women's Status. The College Music Society report no. 5. Boulder, CO: College Music Society.

_. 1974. "Women in the Profession of Higher Education." College Music Symposium 40:55-61.

Boyd, Tammy, Rosa Cintrón, and Mia Alexander-Snow. 2010. "The Experience of Being a Junior Minority Female Faculty Member." Forum on Public Policy: A Journal of the Oxford Round Table 2:1-23. http://forumonpublicpolicy .com/spring2010.vol2010/spring2010archive/boyd.pdf.

Colbeck, Carol, and Robert Drago. 2005. "Accept, Avoid, Resist: How Faculty Members Respond to Bias against Caregiving ... and How Departments Can Help." Change: The Magazine of Higher Learning 37(6): 10-19. 
Cooper, Joanne E., and Dannelle D. Stevens. 2002. Tenure in the Sacred Grove: Issues and Strategies for Women and Minority Faculty. Albany: State University of New York Press.

Curtis, John. 2014. "Data Point." Chronicle of Higher Education 60 (31): A23.

Damasco, Ione, and Dracine Hodges. 2012. "Tenure and Promotion Experiences of Academic Librarians of Color." College and Research Libraries 73 (3): 279-301, doi: 10.5860/crl-244.

Dehaas, Josh. 2012. "The 2013 Maclean's University Rankings." Maclean's, 1 November. http://www.macleans.ca/education/uniandcollege /2013-university-rankings/.

Diggs, Gregory A., Dorothy F. Garrison-Wade, Diane Estrada, and Rene Galindo. 2009. "Smiling Faces and Colored Spaces: The Experiences of Faculty of Color Pursuing Tenure in the Academy." Urban Review 41:312-33.

Dobbie, David, and Ian Robinson. 2008. "Reorganizing Higher Education in the United States and Canada." Labor Studies Journal 33 (2): 117-40.

Dooris, Michael J., and Marianne Guidos. 2006. "Tenure Achievement Rates at Research Universities." Paper presented at the Annual Forum of the Association for Institutional Research. Education 37 (3): 555-68.

Dwyer, Mary. 2013. "Measuring Excellence." Maclean's, 30 October. http:// www.macleans.ca/education/unirankings/measuring-excellence-2-2/.

Fenelon, James. 2003. "Race, Research, and Tenure: Institutional Credibility and the Incorporation of African, Latino, and American Indian Faculty." Journal of Black Studies 34 (1): 87-100.

Finkel, Susan K., and Steven G. Olswang. 1996. "Child Rearing as a Career Impediment to Women Assistant Professors." Review of Higher Education 19 (2): $123-39$.

Gould, Elizabeth. 2011. "Publish(ed) and Perish(ing) in Music and Music Education." Paper presented at the Leading Music Education International Conference, University of Western Ontario, 28 May-11 June 2011.

Higher Education Arts Data Services. 2010. Data Summaries 2009-2010: Music. Reston, VA: Higher Education Arts Data Services.

Holmes, Sharon L., Lynette Danley Land, and Veronica D. Hinton-Hudson. 2007. "Race Still Matters: Considerations for Mentoring Black Women in Academe." Negro Educational Review 58 (1/2): 105-29.

IBM. 2013. IBM SPSS Statistics for Macintosh, v. 22.o. Armonk, NY: IBM.

Mason, Mary Ann, and Marc Goulden. 2002. "Do Babies Matter?" Academe 88 (6): $21-7$.

-2004. "Do Babies Matter (Part II)?" Academe 9o (6): 11-15.

Mclean, Don, and Dean Jobin-Bevans. 2009. "Survey of University-Based Music Programs in Canada." Intersections 29 (1): 89-104.

Miller, Fredrick, Robert J. Werner, and William Hipp. 2006. Musical Chairs: A Management Handbook for Music Executives in Higher Education. Montana: College Music Society.

Neuls-Bates, Carol. 1976. "The Status of Women in College Music: Preliminary Studies." College Music Society Report no. 1. Proceedings of the Meeting on Women in the Profession, Seventeenth Annual Meeting of the College 
Music Society, University of Iowa, Iowa City, 15 February 1975. Binghamton, NY: College Music Society.

Norrell, J. Elizabeth, and Thomas H. Norrell. 1996. "Faculty and Family Policies in Higher Education." Journal of Family Issues 17 (2): 204-26.

Ornstein, M., P. Stewart, and J. Drakich. (2007). "Promotion at Canadian Universities: The Intersection of Gender, Discipline, and Institution." Canadian Journal of Higher Education 37 (3): 1-25.

Payne, Barbara. 1996. "The Gender Gap: Women on Music Faculties in American Colleges and Universities, 1993-1994." College Music Symposium 36:73-90.

Perna, Laura W. 2001. "Sex and Race Differences in Faculty Tenure and Promotion." Research in Higher Education 42(5): 541-67.

Renton, Barbara Hampton. 1980. The Status of Women in College Music, 197677: A Statistical Study. College Music Society report no. 2. Renton, VA: College Music Society.

Rosen, Ruth. 1999. "Secrets of the Second Sex in Scholarly Life." Chronicle of Higher Education, 30 July, A48.

"Sessional Concerns." 2007. Chair's report to the UVic Academic Women's Caucus. https:/awcuvic.wordpress.com/current-issues/sessional-concerns/.

Statistics Canada. 2011. "Ethnic Origin Reference Guide, National Household Survey, 2011." Catalogue no. 99-010-XWE2011006. https://www12.statcan. gc.ca/nhs-enm/2011/ref/guides/99-010-X/99-010-X2011006-eng.cfm.

Stewart, Penni, Michael Ornstein, and Janice Drakich. 2009. "Gender and Promotion at Canadian Universities." Canadian Review of Sociology 46 (1): $59-85$.

Suitor, J. Jill, Dorothy Mecom, and Ilana S. Feld. 2001. "Gender, Household Labor, and Scholarly Productivity among University Professors." Gender Issues 19 (4): 50-67.

Thomas, Earl. 2006. "Higher Education's Challenge: Recruiting and Retaining Minority Faculty." Hispanic Outlook in Higher Education 16 (22): 64.

Trower, Cathy A. 2002. "Why so Few Minority Faculty and What to Do? Diversifying the Region's Professoriate." Connection: New England's Journal of Higher Education 17 (2): 25-7.

Wright, Ednita M., and Diane S. Young. 2001. "Mothers Making Tenure.” Journal of Social Work Education 37 (3): 555-68.

\section{Appendix A: Survey of Tenure-Stream Faculty in Canadian Post-Secondary Music Programs}

\section{Eligibility}

The next three questions will determine if your administrative unit is what we are looking for in this study.

1. Does the administrative unit for which you are responsible have a process for professorial rank faculty tenure? (Response required)

$\square$ Yes

No 
2. Does the administrative unit for which you are responsible offer a four-year or four-plus-year degree or major in music, or include music-related instruction as a part of your four-plus-year degree or after-degree programs? (Response required)

$\square$ Yes

$\square$ No

3. Does the administrative unit for which you are responsible have one of the following: (a) a faculty dedicated to music instruction; (b) a university school of music or conservatory; or (c) music instruction that exists as part of a larger faculty, department, or other academic administrative unit? (Response required)

$\square$ Yes

$\square$ No

If you answered "yes" to all three questions, please proceed to the next page of the survey.

\section{Part 1: Profile of Current Faculty}

Please reply to the following questions relative to the music administrative unit for which you are responsible. If you are responsible for an educational unit, please answer in reference to your music-related faculty only. You will be asked to "count" faculty size in two ways:

Full-time equivalents: Consider full-time equivalency (FTEs). For example, a faculty member who has a 50 per cent appointment in your music administrative unit should be counted as .5 FTE.

Head counts: The number of individuals, regardless of FTE.

4. How many music-specific faculty members are there in your administrative unit? Consider all types of appointment: clinical or other non-tenure track, tenured, and in-tenure track. Enter your answer in the boxes below.

FTE: Use whole numbers and decimals, for example, 4.2

Head count: Whole numbers only

5. How many of these music-specific faculty members are currently in the professorial-rank tenure track but not yet tenured? Enter your answer in the boxes below.

FTE: Use whole numbers and decimals, for example, 4.25

Head count: Whole numbers only

6. Over the last five academic years (in other words, beginning with 2008-9), how many of these professorial-rank faculty members (head count) applied for and received tenure?

Head count: Whole numbers only

Comments (optional)

7. Over the last five academic years (in other words, beginning with 2008-9), how many of these professorial-rank faculty members (head count) applied for, but did not receive tenure?

Head count: Whole numbers only 
Comments (optional)

8. Over the last five academic years (in other words, beginning with 2008-9), how many of these professorial-rank faculty members (head count) were eligible for tenure but did not apply?

Head count: Whole numbers only

Comments (optional)

9. At your administrative unit, may professorial-rank faculty members apply or request that the "clock" to tenure be paused?

$\square$ Yes

No (Note: if “no," please skip \#10)

10. Over the last five academic years (in other words, beginning with 2008-9), how many music-specific professorial-rank faculty members (head count) who were on a tenure track had "the clock" paused?

Head count: Whole numbers only

Comments (optional)

11. At your administrative unit, is there a formal mentoring program for professorial-rank tenure-track faculty that occurs on a regular, systematic basis?

$\square$ Yes

No

Other (please specify):

\section{Part 2: Academic and Tenure Status of Professorial-Rank Faculty, 2012-13 Academic Year}

The final section of the survey focuses on the demographic and professional characteristics of your currently tenured or tenure-stream professorial-rank music faculty, including those about whom a tenure action or decision was made during 2012-13.

Please consider only the academic year just completed, the 2012-13 academic year.

We are not interested in the names of any individuals. So in these next questions we use the term "Faculty Member $\#$ " for each individual about whom we are asking you to provide information.

There are six types of tenure status or action about which we are asking:

1. Already had tenure prior to 2012-13; no tenure action taken or needed

2. Non-tenured; with no tenure action necessary or taken during 2012-13

3. Tenure approved during 2012-13

4. Tenure denied during 2012-13

5. Tenure applied for during 2012-13 but a decision was delayed

6. Was eligible to apply for tenure during 2012-13 but did not apply 
12. Please complete the following table for only tenure-stream professorial-rank music faculty regarding their tenure status during the just completed 2012-13 academic year.

There are spaces for fifteen entries [only one field is provided here as an example]. If you need more space, please photocopy the last page and enter information there.

\begin{tabular}{|c|c|c|c|c|c|}
\hline $\begin{array}{l}\text { Faculty } \\
\text { member \#2 }\end{array}$ & $\begin{array}{l}\text { Rank during } \\
\text { 2012-13 }\end{array}$ & Gender & Race/ethnicity & $\begin{array}{l}\text { Primary } \\
\text { appointment }\end{array}$ & Tenure status \\
\hline & $\begin{array}{l}\text { - Assistant } \\
\text { professor } \\
\text { - Associate } \\
\text { professor, } \\
\text { without } \\
\text { tenure } \\
\text { - Associate } \\
\text { professor, } \\
\text { with tenure } \\
\text { - Full professor }\end{array}$ & $\begin{array}{l}\text { - } \text { Male } \\
\text { - Female }\end{array}$ & $\begin{array}{l}\text { - Bi-racial or } \\
\text { mixed race } \\
\text { - Black/African } \\
\text { descent } \\
\text { - Caribbean } \\
\text { - East/South- } \\
\text { east Asian } \\
\text { (e.g., China/ } \\
\text { Taiwan, } \\
\text { North/South } \\
\text { Korea, Japan, } \\
\text { Thailand, } \\
\text { Vietnam) } \\
\text { - First Nations, } \\
\text { Inuit, Metis } \\
\text { - Hispanic/ } \\
\text { Latino } \\
\text { Pacific } \\
\text { Islander } \\
\text { South Asian } \\
\text { (e.g., India, } \\
\text { Pakistan, } \\
\text { Bangladesh, } \\
\text { Sri Lanka) } \\
\text { White } \\
\text { non-Hispanic } \\
\text { Uncertain } \\
\end{array}$ & $\begin{array}{l}\text { - Brass } \\
\text { - Composition } \\
\text { - Conducting: } \\
\text { choral } \\
\text { - Conducting: } \\
\text { orchestra } \\
\text { - Conducting: } \\
\text { winds/ } \\
\text { percussion/ } \\
\text { bands } \\
\text { - Early music } \\
\text { Ethnomusic- } \\
\text { ology } \\
\text { - Jazz } \\
\text { - Music } \\
\text { - Business/ } \\
\text { administration } \\
\text { - Music } \\
\text { technology } \\
\text { - Music theory } \\
\text { - Music } \\
\text { therapy } \\
\text { - Music } \\
\text { education } \\
\text { - Musicology/ } \\
\text { historical } \\
\text { musicology } \\
\text { - Opera/music- } \\
\text { al theatre } \\
\text { - Percussion } \\
\text { - Piano/organ/ } \\
\text { - Peyboard } \\
\text { - } \text { music } \\
\text { - Woice } \\
\text { - World music }\end{array}$ & $\begin{array}{l}\text { Already } \\
\text { tenured, no } \\
\text { action taken } \\
\text { or needed } \\
\text { - Non-tenured; } \\
\text { no tenure } \\
\text { action taken } \\
\text { or needed, } \\
\text { 2012-13 } \\
\text { - Tenure was } \\
\text { approved dur- } \\
\text { ing 2012-13 } \\
\text { Tenure } \\
\text { was denied } \\
\text { 2012-13 } \\
\text { Tenure was } \\
\text { applied } \\
\text { for during } \\
2012-13 \text {, but } \\
\text { a decision } \\
\text { was delayed } \\
\text { Was eligible } \\
\text { to apply } \\
\text { for tenure } \\
2012-13 ; \text { did } \\
\text { not apply } \\
\end{array}$ \\
\hline
\end{tabular}

\section{Appendix B}

Descriptions from a response of "Other" about the existence of a formal mentoring program (Q11)

1. In this administrative unit, there is a good deal of informal collegial mentoring for tenure-track colleagues, but varies from case to case. At more central levels, there are formal information sessions and workshops for new faculty and especially for those approaching a tenure review; mentoring resources are normally made through those programs. The 
sessions/workshops are offered regularly and systematically, by the Faculty Association (collective bargaining association) and also by Faculty Relations (a unit in the Provost's Office), but attendance is not mandatory. In this administrative unit, there is a formal and systematic process for a faculty member approaching a reappointment or tenure review to meet with the Head to ensure all facets of the review process are properly understood and the required materials are in order. The first purpose of this process is to ensure procedural clarity and avoid unnecessary procedural problems, but the Head also advises the candidate on the most effective ways to present his or her dossier, whether there any gaps in the dossier, whether concerns might be raised, and so forth. Since there are normally two reappointment reviews before a tenure review, this procedure for meeting periodically with the Head does amount to regular, systematic, and formal process, at which feedback and counsel are given. Not mentoring per se, but clear information and feedback that is fundamentally important for a candidate's success.

2. Mentoring is done informally within the discipline.

3. Professors can request a mentor through the Centre for Academic Leadership, which also offers workshops on tenure. Professors may also seek a mentor through the union (APUO).

4. There are informal mentoring opportunities, and a formal process guided by the Director.

5. Once a year one-on-one session with Dean

6. Mentoring is done informally within the discipline

7. Informal assignment of Senior Staff mentor in area of specialization, several central admin support programs available.

\section{Appendix C}

Comments from responders regarding the number of faculty who have requested to pause the tenure clock (Q10)

1. During maternity leave

2. It's not so much a pause, but actually a request to extend the time before applying for tenure (for one or two years).

3. Mentioned above ("one has a deferral")

4. One of the recently tenured professors had asked to pause the clock before 2008.

5. One year unpaid leave

\section{Appendix D}

Comments from responders regarding tenure actions of the last five academic years (2008-9) (Q6-8)

1. Last tenure track hire was 2002 
2. One of the two was converted from Limited Term

3. Three appointed after 2008-9

4. Tenure-track professors must apply for tenure after five years.

5. This person left the institution before being reviewed for tenure

6. One applied [for tenure] but was given an extension

7. This is not applicable. The university has an automatic tenure clock

8. Once has a deferral

\begin{abstract}
This study provides a snapshot of tenure at Canadian post-secondary music institutions, with a particular focus on gender and race/ethnicity. The data show tenure has been granted at high rates over a five-year period, and that women are no more or less likely to achieve tenure than men. However, more men than women hold both tenured and tenure-track positions, at a ratio of 2:1. The sample size of non-white faculty was not large enough to conduct statistical analyses about tenure rates in relation to race/ ethnicity, although the extremely low rates of non-white tenure-track faculty suggest that diversity remains a concern in post-secondary music programs.
\end{abstract}

\title{
RÉSUMÉ
}

Cette étude donne un aperçu de l'obtention de la permanence dans les institutions canadiennes universitaires d'enseignement de la musique, en se concentrant en particulier sur les facteurs de genre et de race/ethnicité. Les données montrent que la permanence a été octroyée à un taux élevé sur une période de cinq ans, et que les femmes n’ont pas plus ou moins de chances de l'obtenir que les hommes. Cependant, il a été observé que plus d'hommes que de femmes occupent les postes réunis avec permanence et menant à la permanence, et ce, dans une proportion de 2 à 1 . L'échantillon des professeurs non-blanc n'était pas suffisamment important pour effectuer des analyses statistiques sur les taux de permanence en rapport avec la race et l'ethnicité, bien que les taux très bas de non-blancs à des postes menant à la permanence suggèrent que la diversité demeure une préoccupation dans les programmes postsecondaires d'enseignement de la musique.

\section{BIOGRAPHIES}

Dr. Louis Bergonzi is the Daniel J. Perrino Professor in Music Education, and Professor of Orchestral Conducting at the University of Illinois, where he conducts the Philharmonia Orchestra. His current research investigates whether music classrooms, peers, and teachers are more supportive of all students than non-music counterparts. (bergonzi@illinois.edu)

Dr. Deanna Yerichuk holds a PhD in Music Education from the University of Toronto, where her research focused on community music and nation-building in Canada's social reform era. She currently lives in Edmonton, Alberta with her family, 
where she continues her work as a Visiting Researcher at the University of Alberta. (dyerichu@ualberta.ca)

Kiera Galway is a PhD Candidate in Music Education at the University of Toronto, exploring the ways community musicians in Canada use music to mediate experience in space and place. Kiera currently teaches in the Education faculty at Memorial University in St. John's, NL and is Director of Music at the Basilica of St. John the Baptist (kiera.galway@mun.ca).

Dr. Elizabeth Gould serves as Associate Professor in Music Education at the University of Toronto. Her research focuses on gender and sexuality in the context of feminisms, Deleuzian, and queer theories. (e.gould@utoronto.ca) 